\title{
Managing Work-Family Conflict and Work Stress through Job Satisfaction and Its Impact on Employee Performance
}

\author{
I Gede Riana ${ }^{1 *}$, Ni Luh Putu Wiagustini ${ }^{1}$, Kadek Iin Dwijayanti¹, I Gede Rihayana ${ }^{2}$
}

\begin{abstract}
Work satisfaction has an essential role in reducing work stress and work-family conflict. This research aims to analyze the influence of work-family conflict and work stress on the work satisfaction and performance of employees. The sample in this research is 46 married female employees. The data analysis technique used is the Partial Least Square (PLS) by using WarpPLS. The results show that; work-family conflict has a significant and negative influence on job satisfaction. Work-family conflict has a significant and negative influence on employee performance. Work stress has a negative and significant influence on job satisfaction. Work stress has a negative and insignificant influence on employee performance. The analysis results provide information that work-family conflict and work stress has an indirect impact on employee performance through job satisfaction. Furthermore, the indirect effects of work-family conflict on employee performance through job satisfaction is a full mediation. Here, a full mediation means that job satisfaction has a strategic role in reducing the work stress and workfamily conflict so that it does not have a significant impact on employee performance. Job satisfaction can be improved by providing feelings of fairness so that women can be satisfied with their job, conducting promotions, and supervisions. Finally, the social support of co-workers and management in the form of implementing family-friendly policies is much needed to maintain job satisfaction.
\end{abstract}

Keywords: Work-family conflict, work stress, job satisfaction, employee performance.

\section{Introduction}

Performance is a multi-component concept that can be differentiated into three aspects, namely process, involvement, and behavior based on the expected results (Pradhan and Jena [1]). The basic idea of performance is frequently related to skills of employees in producing work results, it may be regarding quality or quantity, in performing their job (Boyatzis [2]). Ndulue and Ekechukwu [3] state that performance is defined as a function of individual ability, skill, and effort in a given situation. Employee performance is closely related to the expertise of the organization in managing their available human resources and providing a conducive work environment condition. According to Ali and Abid [4], employee performance can be viewed as an activity in which an individual performing the task assigned successfully.

Women are an essential part of the human resources department that contribute to the development of the organization through the public role. The role changes of women from household mothers (domestic) to career women (public) makes them have a dual career (Nurak et al. [5]).

${ }^{1}$ Faculty of Economics and Business, Department of Management, Universitas Udayana, Kampus Bukit Jimbaran, Denpasar, Bali, Indonesia 80362.

${ }^{2}$ Faculty of Economics and Business, Department of Management, Universitas Mahasaraswati, Л. Kamboja 11A, Denpasar, Bali, Indonesia 80233. Email: gederiana@unud.ac.id

* Corresponding author
Economically, husbands and wives that work (twoworker family) can increase the welfare of the family. However, career women tend to have role conflicts. Retnaningrum and Musadieq [6] stated that work-family conflict has a negative impact on employee performance.

Aside from work-family conflict, employee performance is also very dependant on job satisfaction and work stress level (Anwar et al. [7]). According Shaju, [8]. job satisfaction is a psychological attribute of the employee perception regarding how well their work produces results, and this finding is essential. Satisfied employees will allocate maximum contribution to the organization (Riana [9]) and tend to continue working in the same organization and have an organizational behavior that exceeds their job and role description. Conversely, Nurak and Riana [10] explained that unsatisfied employees tend to oppose the organizational policies, cause commotions in work, and may even be involved in counterproductive behaviors.

The dissatisfaction in work is frequently triggered by the inability of the employee to manage their work stress level. The research by Nabirye [11] showed that there is a significant negative relationship between job satisfaction and work stress. High work stress of employees can result in the loss of job satisfaction [12]. Afterward, Riyadi [13] stated that work stress might decrease the employee performance and job satisfaction, thus work stress is one of the critical predictors which must be managed 
because it can trigger various counterproductive work behavior in the workplace (Riana [9]).

Several research findings related to the influence of work-family conflict and work stress on job satisfaction and employee performance show that it is still debatable. The research conducted by Roboth [14], Retnaningrum and Musadieq [6], and Jackson and Arianto [15] stated that work-family conflict has a negative and significant influence on employee performance. However, some other studies, such as by Nart and Batur [16], Warokka and Febrilia [17], stated that work-family conflict does not have a significant influence on the employee performance. Several other studies noted that stress has a negative and significant impact on job satisfaction (Riyadi [13], Riaz et al. [18]). The studies conducted by Noermijati and Primasari [19] and Agrawal [20] stated that work stress does not have a significant influence on job satisfaction. Furthermore, Riyadi [13], Noermijati and Primasari [19], and Than et al. [21] stated that work stress can significantly influence employee performance, while the research by Nart and Batur [16] and Rizwan et al. [22] indicated that work stress has an insignificant influence on employee performance. The differences between some previous research findings show that there is still a gap which needs further studies.

\section{Methods}

\section{Hypotheses Construction}

Work-family conflict is one of the inter-role conflicts between the role at work and the role in the family. It is considered as a problem for women who work seriously in their working environment (Roboth [14]). Work-Family conflict is a form of conflict which emerges when the demand from the role in work and family is not mutually aligned in several situations (Buhali, and Margaretha [23]). Asfahyadin et al. [24] stated that work-family conflict could influence the work behavior which may eventually have a negative impact on the performance of employees. Furthermore, the number of children, amount of time used to take care of household and work matters, and the unavailability of support from their spouse and family is among the triggers of a workfamily conflict (Cinamon and Rich [25]). According to Nurhaenih [26], work-family conflict may result in the fulfillment of one role but will disturb the other function. Thus, this will influence their behaviors in the workplace, among others is the performance of the employee.

Other than work-family conflict, employee performance may also be influenced by the work stress level (Roboth [14]). Work stress is the tense condition felt by employees which could impact their emotion, thinking process, and employee condition (Khuong and Yen [27]). A high level of stress may disturb the employee in adapting to the organizational environment. As a result, symptoms of tension may develop in the employee who will upset them in performing their job. Khuong and Yen [27] stated that work stress has a negative and significant influence on performance. The higher work stress level, the higher pressure felt by the employees in working which would result in a lower work achievement contributed by the employee (Mansour and Elmorsey [28]).

Work satisfaction is among the critical predictors that can improve employee performance. According to Shaju [8], job satisfaction is the results of employee perception regarding how well their work is assessed. The research by Anwar et al. [7] revealed that employees that feel satisfied in their workplace would have a positive impact on their performance. Meanwhile, Noermijati and Primasari [19], stated that employees satisfied with their work tend to provide a positive impact on the organization resulting in a more conducive organizational condition.

Many researchers have studied the influence of work-family conflict on job satisfaction. Warokka and Febrilia [17], stated that work-family conflict has a negative and significant impact on job satisfaction. In other words, employees that have a high level of work-family conflict tend to have lower job satisfaction. Bruck et al. [29] revealed that workfamily conflict has a negative and significant influence on job satisfaction. Likewise, the research conducted by Amelia [30], Ahmed et al. [31], Boles et al. [32], Goodarzi and Hatami [33], and Retnaningrum and Musadieq [6] stated that work-family conflict has a negative and significant influence on job satisfaction. Likewise, the lower the work-family conflict, the higher the job satisfaction. The research by Asfahyadin et al. [24] stated that work-family conflict has a negative and significant influence on employee performance. Work-family conflict may potentially trigger several disruptions in the role balance in performing a job, resulting in the tendency to have a lower employee performance (Retnaningrum and Musadieq [6], Roboth [14], Jackson and Arianto [15], Amelia [30] and Li et al. [34]).

Based on the review above, the hypothesis proposed is as follows.

H1: Work-family conflict has a negative and significant influence on job satisfaction.

H2: Work-family conflict has a negative and significant influence on employee performance

Excessive work stress may trigger several symptoms, both physiologically and psychologically, in 
performing their job. The research regarding the influence of work stress on job satisfaction was conducted by Rizwan et al. [22], showing that work stress has a negative and significant impact on job satisfaction. The research by Riyadi [13] and Riaz et al. [18] explained that work stress, such as excessive workload, work ambiguity, and limited work time has a negative and significant influence on job satisfaction. The pressures felt in workplace decreases the ability of employees to contribute optimally towards performance. Furthermore, the higher work stress of employees, increasing the performance achievable by the employees. Some previous studies also stated that with a higher level of work stress, incapacitates the job satisfaction and performance (Riyadi [13], Roboth [14], Noermijati and Primasari [19], Than et al. [21], Asfahyadin et al. [24], Khuong and Yen [27], Shahu and Gole [35]).

Thus, the research hypothesis proposed is as follows.

H3: Work stress has a negative and significant influence on job satisfaction.

H4: Work stress has a negative and significant influence on employee performance.

Every organization wants his entire employee to be satisfied because it can impact on employee's performance. Ndulue and Ekechukwu [3], stated that satisfaction regarding salary, supervision, work environment, colleagues, and satisfaction regarding promotion becomes the main focus of employees to feel satisfied in the workplace. Talasaz et al. [36] stated that job satisfaction has a positive impact on employee performance. The higher job satisfaction impact improving the performance of employees tend to be. The research by Shahu and Gole [35], Riyadi [13], Goodarzi and Hatami [33], Noermijati and Primasari [19], and Retnaningrum and Musadieq [6] showed that job satisfaction has a positive and significant influence on employee performance.

Thus, the research hypothesis proposed is as follows. H5: Job satisfaction has a positive and significant influence on employee performance.

\section{Research Method}

This study is conducted in The Balai Wilayah Sungai Bali-Penida, Ditjen Sumber Daya Air, Kementerian Pekerjaan Umum dan Perumahan Rakyat (PUPR), Bali. The population of this study is all woman employees, and the sample criteria are a married woman who has a husband with employment status in a government employee (Aparatur Sipil Negara - ASN), with a total sample of 46 employees. The respondent's profile is depicted in Table 1. Most of the respondents (41.30\%) are older than 45 years, have a working experience for more than 18 years (50\%), and have undergraduate degree (67\%).
Table 1. Respondents' profile

\begin{tabular}{clrr}
\hline & \multicolumn{1}{c}{ Classification } & Total & Percentage \\
\hline \multirow{3}{*}{ Age (years) } & 26 - 35 Years old & 9 & $19,57 \%$ \\
& 36- 45 Years old & 18 & $39,13 \%$ \\
& $>$ 45 Years old & 19 & $41,30 \%$ \\
\hline \multirow{3}{*}{ Working experience $11-18$ Years } & $7-10$ Years & $15,22 \%$ \\
& $>18$ Years & 16 & $34,78 \%$ \\
\hline \multirow{3}{*}{ Last education } & Associate degree & 23 & $50 \%$ \\
& Undergraduate degree & 9 & $19,57 \%$ \\
& Master's degree & 6 & $67,39 \%$ \\
\hline \multirow{3}{*}{ Number of children } & 2 children & 12 & $13,04 \%$ \\
& 3 children & 24 & $52,17 \%$ \\
\hline
\end{tabular}

More than half of them (52.17\%) have two children. The profile of respondents shows that they are maturity workers (seasoned worker) regarding to the age, working experience, last education, and the number of children. This study is explanatory research using the causality model to analyze the influence of the exogenous variable on the endogenous variable.

This research uses quantitative design by directly distributed questionnaire using Likert scales to measure respondents' perceptions. The scores were scaled from scores (1) is strongly disagree until scores 5 strongly agree. It contains four variables using fourteen indicators. For increasing the responses rate, the data were also collected through interviewing to guidance the respondents lowering falsehood on fill out the questionnaire.

Work-family conflict is measured using three indicators adopted from Greenhaus and Beutell [37], namely time-based conflict (WFC1), strain-based conflict (WFC2), and behavioral based-conflict (WFC3). Work stress is measured using three indicators that are adopted from Yozgart et al. [38], namely work-load (WS1), pressure (WS2), and conflict (WS3). Job satisfaction is measured using five indicators adopted from Leung et al. [39], namely the work itself (JS1), pay (JS2), promotion (JS3), supervisor (JS4), and coworker (JS5). While, employee performance is measured using three indicators elaborated from the studies by Koopmans et al. [40] and Koopmans et al. [41], namely task performance (EP1), contextual performance (EP2), and adaptive performance (EP3). Afterward, to examine the research hypothesis, the collected data are analyzed with the descriptive analysis and inferential analysis using WarpPLS.

\section{Results and Discussions}

The questionnaire instrument test is used to determine the quality of the research data using the validity and reliability test. The test results attained shows a corrected items-total correlation (CITC) 
Tabel 2. Instrument validity and realibity test

\begin{tabular}{|c|c|c|}
\hline Variable & Indicator & CITC (r) \\
\hline \multirow{10}{*}{$\begin{array}{l}\text { Work-family } \\
\text { conflict } \\
\text { (Alpha Cronbach } \\
=0.951 \text { ) }\end{array}$} & WFC11- I do not have time for family activities because it is used up for work & 0.802 \\
\hline & WFC12 - I frequently work on weekends & 0.754 \\
\hline & WFC13 - Excessive work time makes me unable to fulfill my household responsibilities (Family role) & 0.760 \\
\hline & $\begin{array}{l}\text { WFC21- I become emotional when I return home from work, and this prevents me from contributing to the } \\
\text { family }\end{array}$ & 0.881 \\
\hline & WFC22 - The pressure at my workplace causes stress which makes me unable to do what I enjoy in my & 0.736 \\
\hline & $\begin{array}{l}\text { family } \\
\text { WFC23. When I return home from work I am ton tired to narticinate in family activities }\end{array}$ & 0808 \\
\hline & wero - & 0.808 \\
\hline & $\begin{array}{l}\text { WFC31- The activities that make me more effective at work do not help me in improving my role as a } \\
\text { spouse }\end{array}$ & 0.782 \\
\hline & WFC32 - The pressure makes me unable to balance between my responsibilities at work and home & 0.855 \\
\hline & WFC33 - The problem-solving behavior at work is not effective in solving problems at home & 0.874 \\
\hline \multirow{6}{*}{$\begin{array}{l}\text { Work Stress } \\
\text { (Alpha Cronbach } \\
=0.886 \text { ) }\end{array}$} & WS11- I have very limited time to rest & 0.737 \\
\hline & WS12 - There is so much work that I must finish & 0.700 \\
\hline & WS21- My job has a high risk & 0.799 \\
\hline & WS22 - The condition of the work support tools that are not good makes me frustrated & 0.694 \\
\hline & WS31- My family do not support me to work in the office & 0.685 \\
\hline & WS32 - I feel offended if a co-worker rebukes my mistake & 0.603 \\
\hline \multirow{10}{*}{$\begin{array}{l}\text { Job Satisfaction } \\
\text { (Alpha Cronbach } \\
=0.959)\end{array}$} & JS11- The task given is suitable with my ability & 0.804 \\
\hline & JS12 - The job I receive is in line with what I want & 0.825 \\
\hline & JS21- The rewarding system in my workplace is already appropriate & 0.702 \\
\hline & JS22 - The amount and type of allowance I received is also appropriate & 0.835 \\
\hline & JS31- The promotional policies at my workplace is already appropriate & 0.831 \\
\hline & JS32 - Opportunities to improve my career are provided & 0.912 \\
\hline & JS41- The supervisors are objective in evaluating employees & 0.819 \\
\hline & JS42- Supervisors provide rewards for well-performing employees & 0.866 \\
\hline & JS51- The atmosphere at work is developed well & 0.845 \\
\hline & JS52 - The employees respect the individual rights of others & 0.808 \\
\hline \multirow{11}{*}{$\begin{array}{l}\text { Employee } \\
\text { Performance } \\
\text { (Alpha Cronbach } \\
=0.967 \text { ) }\end{array}$} & EP11- I am successful in planning my job and also able to finish my job in alignment with the plan & 0.847 \\
\hline & EP12 - I am always able to finish my job on time & 0.858 \\
\hline & EP13- I am able to perform my job well with little time and effort & 0.895 \\
\hline & EP14 - I am always able to finish my job consistent with the predetermined quality standard & 0.770 \\
\hline & EP21- I am able to cooperate with co-workers & 0.855 \\
\hline & EP22- The amount of work I must finish is in line with the tasks given & 0.777 \\
\hline & EP23 - I start to take on new work when I finish my previous work & 0.895 \\
\hline & EP24- I take on challenging jobs if it is available & 0.857 \\
\hline & EP31- I work by providing creative solutions for new issues that I face & 0.748 \\
\hline & EP32 - I work based on the most current work skills and technology & 0.814 \\
\hline & EP33- I am able to adapt to the job in any situation & 0.919 \\
\hline
\end{tabular}
Source: Primary Data Computation Results 2018

value $(r>0.361)$ and a reliability value (Cronbach alpha $>0.6)$, thus the instrument is valid. The test results are displayed in Table 2.

The model fulfills the reliability criteria if the composite reliability value is greater than 0.70 and the internal consistency reliability value is fulfilled if the

Cronbach's alpha coefficient is greater than 0.60. Table 3, shows that the questionnaire has fulfilled the composite reliability $(>0.70)$ and the internal consistency reliability ( $>0.60)$. Meanwhile, with an AVE value above 0.50 , the model can be fulfilled the discriminant validity. Afterward, the convergent validity test (Table 3), it also shows that the model has fulfilled the convergent validity (combine and cross loading $>0.50$ ). The evaluation of the endogenous $\mathrm{R}^{2}$ refers to the criteria, which: $0.02=$ small, $0.13=$ medium, and $0.26=$ large. Based on the analysis results, the average $\mathrm{R}^{2}$ value is 0.663 . Thus, the model produced has a strong effect.
The evaluation of the goodness of fit inner model is calculated based on the predictive relevance value with a formula of $Q^{2}=1-\left(1-R_{1}^{2}\right)\left(1-R_{2}^{2}\right)=1-$ $(0.445)(0.871)=0.9284$. This means that $92.84 \%$ of the model can be explained by the data sample. Thus, the model has strong goodness of fit (Gof).

All the validity and reliability criteria (discriminant, composite, and convergent) are fulfilled. The next step is to examine the hypothesis using WarpPLS by reviewing the path coefficient result and p-values in Figure 1 and Table 4.

Table 3. Composite reliability and Cronbach`s Alpha

\begin{tabular}{lcccc}
\hline Variables & $\begin{array}{c}\text { Composite } \\
\text { reliability } \\
\text { coefficients }\end{array}$ & $\begin{array}{c}\text { endogeno } \\
\text { us R }\end{array}$ & $\begin{array}{c}\text { Cronbach's } \\
\text { alpha } \\
\text { coefficients }\end{array}$ & AVE \\
\hline WFC & 0.975 & - & 0.961 & 0.928 \\
W stress & 0.914 & - & 0.859 & 0.780 \\
J Sat & 0.961 & 0.455 & 0.949 & 0.831 \\
E Perfm & 0.981 & 0.871 & 0.971 & 0.945 \\
\hline
\end{tabular}

*WfC= work-family conflict, JSat= Job satisfaction, W Stress = work stress, E Perf = Employee performance 
Table 4. Path coefficients summaries

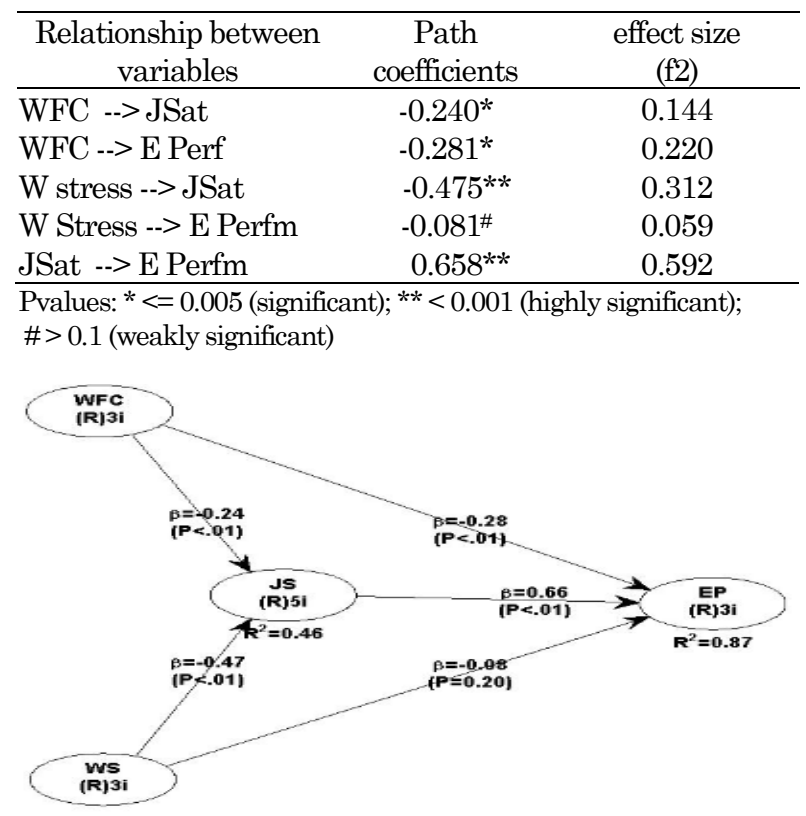

Figure 1. Path values structural models

The effect size (f2) shows the influence strength due to the variation in the exogenous latent variable on the endogenous latent variable. The evaluation criteria (f2) can be categorized into three classes: an $\mathrm{f} 2$ value of 0.02-0.15 (small effect), 0.15-0.35 (moderate effect), and a value $>0.35$ (strong effect). Table 2 shows the average effect size is 0.394. Thus, the pattern relationship between latent variables in this model is strong.

The work-family conflict significantly negative influences on job satisfaction and employee performance. The work stress significantly negative impact on job satisfaction. However, it does not significantly influence the employee performance. The job satisfaction has a strong relationship with the employee performances (see Table 4). Additionally, there are two indirect influences in which the mediation effect can be examined. The first indirect influence, i.e., work-family conflict on the employee performance through job satisfaction is a partial mediation. The second indirect influence, i.e., work stress on employee performance through job satisfaction is a full mediation (see Figure 1).

\section{Discussion}

Married women with a dual career tend to have imbalance role in their work activities, i.e., the role of workers and as housewives. Three types of conflict occur to women with a dual career, namely conflict due to the difficulties in dividing time between work and family, conflict due to the pressure in performing two different roles simultaneously, and the challenges in balancing the behavior between work and family [37]. Based on the descriptive analysis, the mean perception of work-family conflict is 2.31 (low); time-based conflict (2.31); strain-based conflict (2.30). The highest contribution to the workfamily conflict (WFC) is behavioral-based conflict (2.32).

For dual-career women, inability to contribute optimally in both roles is disturbing them. According to Nurhaenih et al. [26], a prolonged work-family conflict may potentially trigger various conditions that can disrupt the behaviors at work which could harm the organization. According to Nurhaenih et al. [26], a prolonged work-family conflict may potentially trigger various conditions that can disrupt the behaviors at work which could harm the organization.

Work-family conflict may also trigger various pressure which may lead to work stress (Nart and Batur [16], Li et al. [34], Khuzaeni et al. [42]). Stress in the workplace is a natural occurrence as it is a form of employee response, physically or mentally, towards the change in the environment they perceive as disturbing, resulting in the feelings of being threatened. Jamadin et al. [43] stated that work stress occurs when an employee is not able to adapt due to the difference in individual behaviors in the organizational environment, both psychologically and regarding conduct. Psychologically, stress may cause work relationship to be less harmonious, uneasy, anxious, experience boredom resulting in the procrastination of work, and the feelings of anxiety. Stress also influences behavior, such as disrupts productivity, become easily agitated, absent from work, and the change in work behavior which may disturb other employees. The inability to overcome the behavioral and psychological symptoms may incapacitate the ability of employees to finish the tasks given to them.

Mansour and Elmorsey [28] stated that work stress is caused by various matters, such as leaders, colleaguees, and supervisors. If it cannot be managed well, work stress tends to decrease performance, but work stress can be intervened, it's just the sources of the stressor can't be removed. Work stress does not always have a negative impact because it can influence employee performance in two ways. First, destructtive stress which can decrease performance. Second, constructive stress which instead stimulates employyees to make extra contributions to the organization. The perception mean of work stress is 2.51 (low); pressure (2.52); conflict (2.49). The highest contribution to the work stress is work overload (2.53). The stress will not give negative impact on the employee's work performance if the environment that potentially triggers work stress is manageable (Noermijati and Primasari [19], Agarwal [20], Jamadin et al. [43]). 
Satisfied employees believe that their contribution towards the organization is in line with expectations. Often, job satisfaction is related to the salary received, the relationship with colleagues, supervision of superiors, fairness in the promotion, and the supportive environment.

Job satisfaction is frequently related to the salary received, the relationship with colleagues, supervision of superiors, fairness in the promotion, and the supportive environment. Work satisfaction can also be illustrated as a pleasant emotional condition which may provide a positive impact, both for employees or another work environment.

The perception mean on job satisfaction is 3.67 (satisfied); satisfaction to the job itself (3.66), reward (3.65), promotion (3.69), and coworker (3.64). The highest contribution to job satisfaction is supervision (3.73). The perceptions mean of employee performance is 3.91 (high); contextual performance (3.90), and adaptive performance (3.86). The highest contribution to employee performance is the task performance (3.93).

This study shows that job satisfaction has an essential role in reducing work stress so that it does not negatively influence employee performance.

Several endeavors to reduce role conflict have been conducted, such as by developing the social support culture between co-workers (Abu Al Rub [44]) and implementing family-friendly policies by management (Rosiana [45]). Management needs to think of how to apply rules that are friendly towards the employees' family welfare to provide security, especially for women. This rule may become an incentive to increase the motivation and commitment to stimulating the increase in performance (Youngcourt and Huffman's [46]). Consequently, management needs to make a guide to monitor the execution of various programs in facilitating the implementation of family-friendly policies. An important note from Youngcourt and Huffman's [46] study is that the implementation of family-friendly policies that performed well can decrease the role conflict which may also reduce the work stress and increase performance. Because of this, social support from coworkers is much needed to decrease work-family conflict (Selvarajan et al. [47]).

\section{Conclusions}

The increasing number of dual-career women may have a negative impact on work performance if it is not well managed. A dual-career makes women having difficulties in dividing time, the pressure at work and home, and challenges in balancing the work and family (Greenhaus and Beutell [37]). Those difficulties can trigger various disruptions at the workplace, such as the increase in work stress level, decrease in job satisfaction, and even incapacitates the performance they can achieve in their job.

The findings in this study show that job satisfaction is an essential mediator in reducing work stress and work-family conflict. Job satisfaction is the level of positive affection a worker has towards their job and the work situation they experience concerning the cognitive and behavioral aspects. The cognitive element of job satisfaction depicts believe of employyees regarding their job and work situation, such as think that their work is interesting, stimulating, pleasure and demanding. The cognitive aspect cannot be separated from the affection aspect, which means that it is highly related to positive feelings because job satisfaction is the interaction of various psychological elements. Meanwhile, the aspects of behavior view the job from the perspective of employee behavior in the job, which is shown from work, perseverance in a position, or work orderly and in a disciplined manner. The equity theory (Adams [48]) stated that employees feel satisfied or dissatisfied depending on whether they feel that there is equity in their job. Equity is measureed based on the contribution employees attained from the organization by comparing themselves with other employees in the same or different environment.

This study has limitations because perspectives may change due to various factors that form and influence it. Thus, this research result only provides an overview of the relationship between variables when the research is conducted. Thereupon, this study is undertaken on working women in all level of management, in which each management level provides a different impact on the work-family conflict and the stress level felt which will influence the job satisfaction and employees' performance.

\section{References}

1. Pradhan, R., K., and Jena, L., K., Employee Performance at Workplace: Conceptual Model and Empirical Validation, Business Perspectives and Research, 5, 2017, pp. 1-17.

2. Boyatzis, R., E., Competencies in the 21st century, Journal of Management Development, 27(1), 2008, pp. 5-12.

3. Ndulue, T. I., and Ekechukwu, H., C. Impact Of Job Satisfaction on Employees Performance: A Study of Nigerian Breweries PLC Kaduna State Branch, Nigeria. Kuwait Chapter of Arabian Journal of Business and Management Review, 5(11), 2016, pp. $13-23$. 
4. Ali, M., and Abid, N, Impact of Stress Antecedents on Work Stress and Employees Performance, International Journal of Business and Management Invention, 4(11), 2015, pp. 63-68.

5. Nurak, L, A. D., Thoyib, A, Noermijati, and Riana, I. G, The Relationship between WorkFamily Conflict, Career Success Orientation and Career Development among Working Women in Indonesia, International Journal of Management Science and Business Administration, 4(2), 2018, pp. 49-56.

6. Retnaningrum, A. K., and Musadieq, M. A., Pengaruh Work-Family Conflict terhadap Kepuasan Kerja dan Kinerja (Studi pada perawat wanita RSUD Wonosari Yogyakarta). Jurnal Administrasi Bisnis (JAB). 36(1), 2016, pp. 7281.

7. Anwar, B.A., Maupa, H., Ali, M., and Ismail, M., The Effects of Work Stress and Compensation on the Employees' Performance through Motivation and Job Satisfaction at the Private Life Insurance Companies in Jakarta, Indonesia, Scientific Research Journal (SCIRJ), 3(9), 2015, pp. 33-36.

8. Shaju. M, A Study on the Impact of Job Satisfaction on Job Performance of Employees Working in Automobile Industry, Punjab, India, Journal of Management Research, 9(1), 2017, pp. $117-130$

9. Riana, I. G, Effects Motivation on Business Performance: The Mediation Role of Job Satisfaction and Leadership (A Study in Village Credit Institutions), European Journal of Business, Economics and Accountancy, 3(2), 2015, pp. 1- 11.

10. Nurak, L. A. D., and Riana, I. G., Examine the Effect of Organizational Justice on Job Satisfaction and Employee Performance, Journal of Management and Marketing Review, 2(3), 2017, pp. 30-37.

11. Nabirye, R. C., Occupational Stress, Job Satisfaction, and Job Performance among Hospital Nurses in Kampala, Uganda. A Dissertation, University of Alabama at Birmingham, in partial fulfillment of the requirements for the degree of Doctor of Philosophy, 2010.

12. Fairbrother, K., and James, W., Workplace Dimensions, Stress and Job Satisfaction, Journal of Managerial Psychology, 18(1), 2003, pp.8-21.

13. Riyadi, S., Effect of Work Motivation, Work Stress and Job Satisfaction on Teacher Performance at Senior High School (SMA) throughout the State Central Tapanuli, Sumatera. IOSR Journal of Humanities and Social Science (IOSR-JHSS), 20(2), 2011, pp. 52-57.

14. Roboth, J. Y., Work Family Conflict, Stres Kerja dan Kinerja Wanita Berperan Ganda pada Yayasan Compassion East Indonesia, Jurnal Riset Bisnis dan Manajemen, 3(1), 2015, pp. 3346.

15. Jackson, and Arianto, Y., Pengaruh WorkFamily Conflict terhadap Kinerja Karyawati PT
Sinta Pertiwi. Jurnal Kreatif: Pemasaran, Sumberdaya Manusia dan Keuangan, 5(1), 2017, pp. 99-111.

16. Nart, S., and Batur, O., The Relation between Work-Family Conflict, Job Stress, Organizational Commitment and Job Performance: A Study on Turkish Primary Teachers, European Journal of Research on Education, 2(2), 2013, pp. 7281.

17. Warokka, A., and Febrilia, I., Work-Family Conflict and Job Performance: Lesson from a Southeast Asian Emerging Market, Journal of Southeast Asian Research, 2015(2015), pp. 1-14.

18. Riaz, M., Ahmad, N., Riaz, M., Murtaza, G., Khan, T., and Firdous, H., Impact of Job Stress on Employee Job Satisfaction, International Review of Management and Business Research, 5(4), 2016, pp. 1370-1382.

19. Noermijati, and Primasari, D., The Effect of Job Stress and Job Motivation on Employees' Performance through Job Satisfaction (A study at PT. Jasa Marga (Persero) Tbk. Surabaya Gempol branch), Journal of Economics, Business, and Accountancy Ventura, 18(1), 2015, pp. 231-240.

20. Agarwal, R. N., Stress, Job Satisfaction and Job Commitment's Relation with Attrition with Special Reference to Indian It Sector, Management and Innovation for Competitive Advantage, 1(1), 2015, pp. 720-731.

21. Than, V. D., Pham, C. H., and Pham, L., Job Stress, Involvement, Satisfaction and Performance of Employees in Garment 10 Corporation in Vietnam, International Journal of Financial Research, 7(3), 2016, pp. 96-109.

22. Rizwan, M., Waseem, A., and Bukhari, S. A., Antecedents of Job Stress and Its impact on Job Performance and Job Satisfaction, International Journal of Learning \& Development, 4(2), 2014, pp.187-203.

23. Buhali, G.A., and Margaretha, M., Pengaruh Work-Family Conflict terhadap Komitmen Organisasi: Kepuasan Kerja sebagai Variabel Mediasi, Jurnal Manajemen, 13(1), 2013, pp.1534.

24. Asfahyadin, A. L., Nur, N., Taufik, M. H., Sabara, G. T., Rosmawaty, Kartini, and Mirad, The Influence of Work-Family Conflict and Work Stress on Employee Performance, International Journal of Management and Applied Science, 3(2), 2017, pp. 1-6.

25. Cinamon, R. G., and Rich., Y., Gender Differences in the Importance of Work and Family Roles: Implication for Work-Family Conflict, Sex Roles, A Journal of Research, 47(1), 2002, pp. 531-541.

26. Nuhaenih, S., and Ujianto, Effect of Work Stress and Role Conflict on Job Satisfaction, Burn Out 
and Performance of Female Nurses in the Sawerigading Palopo Public Hospital, European Journal of Business and Social Sciences, 6(11), March 2018, pp. 204-215.

27. Khuong, M. N., and Yen, V. H., Investigate the Effects of Job Stress on Employee Job Performance a Case Study at Dong Xuyen Industrial Zone, Vietnam, International Journal of Trade, Economics and Finance, 7(2), 2016, pp. 31-37.

28. Mansour R, A, G dan Elmorsey, R. M., Occupational Stress: Measuring its Impact on Employee Performance and Turnover, European Journal of Business and Management, 8(21), 2016, pp.110.

29. Bruck, C. S., Allen, T. D., and Spector, P. E., The Relation between Work-Family Conflict and Job Satisfaction: A Finer-Grained Analysis, Journal of Vocational Behavior, 60(1), 2002, pp. 336-353.

30. Amelia, A., Pengaruh Work to Family Conflict dan Family to Work Conflict terhadap Kepuasan dalam Bekerja, Keinginan Pindah Tempat Kerja, dan Kinerja Karyawan, Jurnal Ekonomi dan Bisnis, 4(3), 2010, pp. 201-219.

31. Ahmed, B. M., Muddasar, M., dan Perviaz, S., The Impact of Work-Family Conflict and Pay on Employee Job Satisfaction with the Moderating Affect of Perceived Supervisor Support in Pakistan Banking Sector, Global Journal of Management and Business Research, 12(6), 2012, pp. 3744.

32. Boles, J. S., Johnston, M. W., dan Hair, J. F., Role Stress, Work-Family Conflict and Emotional Exhaustion: Inter-Relationships and Effects on Some Work-Related Consequences, Journal of Personal Selling \& Sales Management, 17(1), 2014, pp. 17-28.

33. Goodarzi, H. T., and Hatami, S., The Effect of Work-Family Conflict and Work-Family Facilitation on Job Satisfaction and Job Performance in National Iranian Drilling (NIDC), Indian Journal of Fundamental and Applied Life Sciences, 5(2), 2015, pp. 2821-2830.

34. Li, C., Lu, J., dan Zhang, Y., Cross-Domain Effects of Work-Family Conflict on Organizational Commitment and Performance, Social Behavior and Personality, 41(10), 2013, pp. 16411654.

35. Shahu, R., dan Gole, S. V., Effect of Job Stress and Job Satisfaction on Performance: An Empirical Study, AIMS International Journal of Management, 2(3), 2008, pp. 237-246.

36. Talasaz, Z. H., Saadoldin, S. N., dan Shakeri, M. T., The Relationship between Job Satisfaction and Job Performance among Midwives Working in Healthcare Centers of Mashhad, Iran. Journal of Midwifery and Reproductive Health, 2(3), 2014, pp. 157-164.
37. Greenhaus, J.H., and Beutell, N. J., Sources of Conflict between Work and Family Roles. Academy of Management Review, 10(1), 1985, pp. 76-88.

38. Yozgat, U., Assoc. Yurtkoru, S., and Bilginoglu, E., Job Stress and Job Performance among Employees in Public Sector in Istanbul: Examining the Moderating Role of Emotional Intelligence, Social and Behavior Sciences, 75(1), 2013, pp. 518-524.

39. Leung, M. Janet S. dan Chan. Y.S., (Adjusting Stressors - Job-Demand Stress in Preventing Rustout/Burnout in Estimators. Surveying and Built Environment, 18(1), 2007, pp. 17-26.

40. Koopmans, L., Conceptual Frameworks of Individual Work Performance: A Systematic Review, Journal of Economic and Management, 53(8), 2011, pp. $856-866$.

41. Koopmans, L., Bernards, C.M., Hildebrant, V.H., Vet, H.C.W. de, Beek, A.J. van der., Construct Validity of the Individual Work Performance Questionnaire, Journal of Occupational and Environment Medicine, 56(3), 2014, pp. 331337.

42. Khuzaeni, M.S., Idrus, D., and Solimun., The Influence of Work Culture, Work Stress to the Job Satisfaction and Employees Performance in the State Treasury Service Office in Jakarta, Indonesia, IOSR Journal of Business and Management (IOSR-JBM), 9(2), 2013, pp. 49-54.

43. Jamadin, N., Samsiah, M., Zurwina, S. and Fauziah, N., Work-Family Conflict and Stress: Evidence from Malaysia, Journal of Economics, Business and Management, 3(2), 2015,pp.309312.

44. Abu Al Rub, R. F., Job Stress, Job Performance, and Social Support among Hospital Nurses, Journal of Nursing Scholarship, 36(1), 2004, pp. 73-78.

45. Rosiana, D., Mengatasi Konflik Peran Sebagai Karyawan dan Ibu Rumah Tangga pada Tenaga Kerja Perempuan di Indonesia, Mimbar, XXIII (2), 2007, pp. 271-287.

46. Youngcourt, S dan A, H. Huffman., FamilyFriendly Policies in the Police: Implications for Work-Family Conflict, Applied Psychology in Criminal Justice, 1(2), 2005, pp. 138-162.

47. Selvarajan, Barjinder, S., Peggy A., Cloninger. Role of Personality and Effect on the Social Support and Work-Family Conflict Relationship, Journal of Vocational Behavior, 94, 2016, pp. 3956.

48. Adams, J. S. Toward an Understanding of Inequity, Journal of Abnormal Social Psychology, 67(1), 1963, pp. 422-436. 